\title{
The Assessment of Soil Fertility Index for Evaluation of Rice Production in Karanganyar Regency
}

\author{
Prastiwi Prastiwi ${ }^{1}$, Sumani Sumani ${ }^{1}$, Minardi Slamet ${ }^{1}$, Suntoro Suntoro $^{1} \&$ Supriyadi Supriyadi $^{1}$ \\ ${ }^{1}$ Department of Soil Science, Faculty of Agriculture, Sebelas Maret University, Surakarta, Indonesia \\ Correspondence: Supriyadi, Department of Soil Science, Faculty of Agriculture, Sebelas Maret University, Jl. Ir. \\ Sutami 36A, Surakarta 57126, Indonesia.
}

Received: June 21, 2020

Accepted: March 17, 2021

Online Published: March 23, 2021

doi:10.5539/mas.v15n2p63

URL: https://doi.org/10.5539/mas.v15n2p63

\begin{abstract}
Rice (Oryza sativa L.) is a very important food crop because the result is used as a staple food for residents in Indonesia. Higher food fulfillment leads to the increase of rice production of the Mojogedang sub-district. Paddy fields that have high soil fertility will produce good rice productivity. Rice fields in Mojogedang Sub-district are managed with organic systems and conventional systems, the management of different fields of rice field certainly affects the level of fertility in the paddy fields so it is necessary to evaluate the soil fertility index. The survey area consists of 10 points with organic and conventional management systems. The parameters taken include chemical and biological properties of soil, including; $\mathrm{pH}$, redox potential, C-organic, CEC, base saturation, $\mathrm{P}$ available, available $\mathrm{K}, \mathrm{N}$ Total, $\mathrm{C} / \mathrm{N}$ ratio, and total microbial. The data obtained by performed analysis of the main component principal component analysis (PCA) using statistical applications. Then after complete the calculation of The Soil Fertility Index (SFI) at each point and management system. The results of statistical analysis obtained soil Fertility Index on organic management systems have a class of 4 or very high and in conventional management systems have a class of 3 or High. The value of the index obtained is strongly influenced by the K indicator available where the indicator has a noticeable effect on the various management systems. Increased soil fertility index due to the use of manure that can improve plant nutrients and applied for long periods.
\end{abstract}

Keywords: organic farming, principal component analysis, soil fertility index

\section{Introduction}

Rice (Oryza sativa L.) is an important food plant for most of the world's population (Fageria, 2011), especially for residents in Indonesia. Achieving sustainable and environmentally friendly food security has sparked efforts to find out the right solutions in improving soil and environmental quality (Gupta et al., 2019). The increasing number of population leads to the need for rice as the staple food is also increasing. The number of inhabitants in the Mojogedang sub-district increased by 62,632 while in the previous year 61,1449 people (Central statistic, 2019). Mojogedang is a subdistrict in Karanganyar regency. The land use in the Mojogedang subdistrict is largely a rice paddy area of 2024.74 ha (Central Statistic Agency,2018).

Rice production that needs to be improved to fulfill food such as rice is increasingly high, it is necessary to take monitoring action of Soil Fertility index in Mojogedang sub-district, Karanganyar. The management of different rice fields certainly affects the level of fertility in the paddy fields (Supriyadi, 2018). Land management systems applied to the area are organic farming systems and conventional farming systems. The organic farming system is an agricultural system that only uses natural materials, whether provided by the soil or cultivated by plants (Thomas et al., 2011). The difference in the management system in the rice fields of the Mojogedang subdistrict also makes a difference in the fertility rate of the paddy fields, so it is necessary to evaluate the soil fertility index.

Soil fertility is the potential for soil to provide adequate nutrients and in the form available to plants to ensure the growth and production of crops to be maximized (Sulakhudi et al., 2017; N. Kiboi, 2019). It is important because the evaluation of soil fertility can be used as a reference tool or guideline for the management of nutrients in the soil sustainably with regard to environmental aspects (Khadka et al., 2017). Assessment of Soil Fertility Index can help identify areas of problem or need appropriate special management (Bagherzadeh et al., 2018). Soil Fertility Assessment can provide information to estimate specific indicators of soil fertility to obtain the value of the soil fertility index that can be used to make a recommendation of soil fertility Management (Andrews, 2004; Khaki et al., 2017). In the soil fertility evaluation system, the weight determination of each index is a key factor that affects 
the accuracy of Evaluation (Plant, 2001; Mc Bratney et al., 2014; Chen et al., 2020).

Most of the value calculation of soil fertility is determined by some soil properties such as chemistry, biology, and physical properties. Although each indicator has the same opportunity to be used as the main indicator for determining soil fertility (Ramiro Recena, Victor M., \& Antonio Delgado, 2019). Generally, indicators are used as an indicator of soil fertility such as $\mathrm{pH}, \mathrm{CEC}$, alkaline saturation, total microbial colonies, potential redox, C-Organic, available K (Martinez-Salgado et al., 2010).

Evaluation of soil fertility in various field management practices is rare. Especially in the area of Mojogedang where there is no study of the soil fertility index conducted, it is necessary to analyze the soil Fertility index on rice fields in Mojogedang for the availability and food security for the district area of Mojogedang. That is why knowing the soil fertility index is important for increasing crop production and affecting agriculture in the future.

\subsection{Previous Related Researches}

Some relevant studies are presented for a benefit from the methods and theories of some researchers have done before. It has been compiled from the latest year to oldest:

A study by Supriyadi, Dewi S. W., Nugrahani D., Rahmah A. A., Haryuni, \& Sumani. (2020) entitled "The Assessment of Soil Quality Index for Paddy Fields with Indicator Biology in Jatipurno Districts, Wonogiri" aimed that the provision of manure in organic rice fields increases soil fertility on degraded land.

A study by Khadka, D. S., Lamichane, S. R. Sharestha, \& B. B. Pant. (2017). Evaluation of Soil Fertility Satatus of Regional Agricultural Research Station, Taraha, Sunsari, Nepal” aimed to the importance of a soil fertility.

A study by Bagherzadeh, A., Gholizadeh, A., \& Keshavarzi, A. (2018). Assessment of soil fertility index for potato production using integrated Fuzzy and AHP approaches, Northeast of Iran" aimed at the level of soil Fertility index in various values.

A study by Mustikaningrum, I. A., Supriyadi, Herawati A., Purwanto P., \& Sumani S. (2018) entitled "Soil quality assessment in organic and non-organic paddy fields in Susukan, Indonesia" aimed to compare the soil quality on organic and non-organic paddy fields.

A study by Supriyadi., Rachmawati Septiana, Herawati A., \& Purwanto. (2018). Entitled "Soil Quality Assessment of The Rainfed Lowland Rice Field Under Organic and Conventional Farming Systems in Kaliwungu" aimed at the different rice fields management affects the level of fertility in the paddy fields.

A study by Xie, L. W., Zhong, J., Chen, F. F., Cao, F. X., Li, J. J., and Wu, L. C. (2015). Entitled "Evaluation of Soil Fertility in The Succession Of Karst Rocky Desertification Using Principal Component Analysis" aimed at the method that used in calculating the soil fertility index using PCA (Pearson Component Analysis).

A study by Reeuwijk, L. P. V.(2002). Entitled "Procedures for soil analysis 6 nd edition" aimed at the procedure of method in the analysis of the soil chemical fertility parameters.

Wander, M. M., Gerald, L. W., Nissen, T. M., Bollero, G. A., Andrews, S. S., \& Deborah, A. C. (2002). Entitled "Soil quality: Science and process" aimed to determine soil fertility index based on laboratory analysis results and correlation test.

\section{Method}

\subsection{Study Area}

Geographically the location of the study lies $07^{\circ} 01^{\prime} 969^{\prime \prime}$ ' LS and $111^{\circ} 00$ ' $492^{\prime \prime}$ 'BT and has an organic rice field area with an average altitude of 232 above sea level, 0.75 ha and a type of rice crop of rice varieties are Mentik and IR 64. Based on the USDA classification the soil type in the region is Litosol. To assess the change of soil fertility, this research was conducted on the different of paddy fields management, which is organic rice field management system with a dose of organic fertilizer in the form of manure 5 ton/ha, and on conventional land the use of an average NPK fertilizer $188.72 \mathrm{~kg} / \mathrm{ha}$, urea fertilizer $332.61 \mathrm{~kg} / \mathrm{ha}$, and ZA fertilizer $226.9 \mathrm{~kg} / \mathrm{ha}$.

\subsection{Soil Sampling}

A sampling of soil is conducted by purposive sampling based on a unit of a spaced map that has been made (Adepteu et al., 2000; Noviyanto et al., 2017), by the composite that at any point of land was taken at a depth of 0-20 cm with a distance of \pm 1 meter in the direction of the wind, then mixed and blended evenly (composited), and taken as much as approximately $1 \mathrm{~kg}$ (Kaewjai et al., 2020). Soil sampling is done in the organic rice fields Karanganyar regency. According to Supriyadi et al., (2015) soil sampling is done by composite means it can represent the condition of each soil sampling point. 


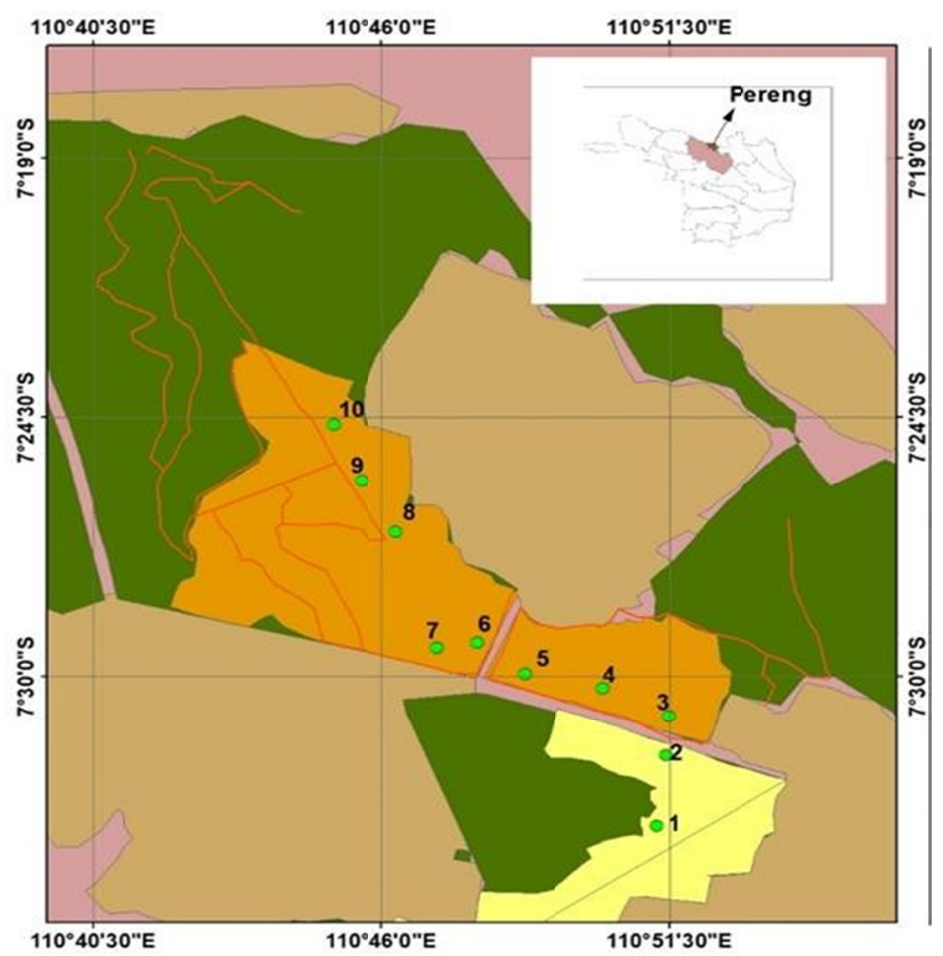

Figure 1. Overlay of map soil sampling

\subsection{Analytical Methods}

Selecting an indicator or parameter to know the Minimum Soil Fertility Indicator (MSFI) is obtained from the interpretation result of the indicator in the form of scoring and merging it into the formulation of Soil Fertility Index (Mukashema, 2007). According to Mueller et al. (2016) says that the parameters consist of physical, chemical, and biological properties. This Parameter will be used as the determinant for the Soil Fertility Index Assessment (Table 1.).

Table 1. Parameters and methods of soil fertility analysis Indicators

\begin{tabular}{lll}
\hline Indicators & Analyze Method & References \\
\hline pH, Eh & Electrometric method; Soil: water suspension (1:5) & (Reeuwijk, 2002) \\
Organic Carbon & Walkey and Black method & (Feng, 2013) \\
Total-N & Kjeldahl method & (Reeuwijk, 2002) \\
Available P & Olsen method & (Reeuwijk, 2002) \\
Available K & Ammonium Acetate 1N Extraction & (Reeuwijk, 2002) \\
CEC & Ammonium Acetate 1N Extraction & (Reeuwijk, 2002) \\
Base Saturation & Ammonium Acetate 1N Extraction; Calculated as the & (Rieeuwijk, 2002) \\
C/N Ratio & proportion of the CEC occupied by basic cations & \\
Total Microbial Colonies & Pour plate method & (The Indonesian Soil \\
\hline
\end{tabular}

Note. Eh= Redox potential, $\mathrm{CEC}=$ Cation exchange capacity

The indicators chosen as MSFI are then given the rate based on the analytical value of the laboratory. To identify relationships among soil fertility parameters Pearson's correlation matrices were calculated (Lantoi et al., 2015).

2.4 Soil Fertility Assessment

After scoring, the soil fertility index assessment was conducted. The soil fertility index calculation eventually displays one final value indicating the value of the soil fertility being analyzed. Assessment of Soil Fertility index was determined in advance indicators and scoring to be integrated into the following formula: To identify 
relationships among soil fertility parameters Pearson's correlation matrices were calculated.

$$
S F I=\left(\frac{\sum_{i=1}^{n} S c i}{N}\right)
$$

Table 2. The Scoring of Soil Fertility Index

\begin{tabular}{cc}
\hline Soil Fertility Index & Score \\
\hline Very Low & $0,00-0,25$ \\
Low & $0,25-0,50$ \\
Moderate & $0,50-0,75$ \\
High & $0,75-0,90$ \\
Very High & $0,90-1,00$
\end{tabular}

Where Sci is an indicator score on each variable, $\mathrm{N}$ is the number of indicators of the scoring calculation results, then in the article based on the fertility index of soil according to Bagherzadeh et al. (2018).

\subsection{Statistical Analysis}

The correlation analysis used an equivalent of $5 \%(\alpha 0.05)$. The two indicators have a strong correlation when Pearson's correlation value approaches 1 or $|-1|$ and the P-value value is less than 0.05 (Zhan-Jun, 2014). MSFI is obtained from the calculation of Principal Component Analysis (PCA) using Minitab software 18 and Microsoft Excell.

\section{Results}

\subsection{Soil Properties}

The chemical and biology properties have different characteristics depending on their land management. Based on the analysis that has been done conditions on organic rice fields have a better chemical and biological value than the conventional management presented in (Table 2.). Analysis of chemical indicators includes total N, base saturation, $\mathrm{P}$ available, $\mathrm{C}-\mathrm{Organic}, \mathrm{CEC}, \mathrm{C} / \mathrm{N}$ ratio, $\mathrm{pH}$, Eh (redox potential), and available $\mathrm{K}$. The analysis of biological indicators includes a total of microbial colonies. The various properties of soil chemistry all results show the average land on the rice field of organic system is higher than on the rice field of a conventional system because the conditions of organic materials in the form of manure into the field of rice fields will decompose to release minerals in the form (Sari, Sudarsono \& Darmawan, 2017) of alkaline cations (Ca, Mg, $\mathrm{Na}, \mathrm{K}$ ). This research is also supported (Supriyadi, 2020) that the provision of manure in organic rice fields increases soil fertility on degraded land. The use of organic materials to improve soil chemical properties such as Base Saturation, Available K, and Available P increases so that it will be able to increase nutrient availability and prevent loss of nutrients due to fatigue. The base saturation results in the organic rice field are higher (55.94\%) compared to conventional $(27.03 \%)$. The high base saturation content indicates the availability of a widely alkaline cation for plant purposes in terms of nutrients (Purwanto, 2008). The provision of organic materials in the form of manure and residual straw over a long time will increase the content of C-organic on rice fields (Chen et al., 2018). The moderate C-organic value (2.80\%) occurs because the production of organic materials from the remnants of plants such as rice straw and crop litter is left to be laid in the rice field.

The total value of the colony on the high organic rice fields $(7.13 \mathrm{Cfu} / \mathrm{g})$ shows the activity of microorganisms in the soil (Wahyuni et al., 2016). The high number of bacteria present in the soil indicates a large number of microorganisms contained in the soil (Supriyadi, 2020). The redox potential value at the research site has a value range of $1.16 \mathrm{mV}-45.04 \mathrm{mV}$ (low reduction) (Liu, 1985). 
Table 3. Results of soil properties analysis in paddy fields of Pereng Village

\begin{tabular}{lll}
\hline Soil Properties & Organic Farming & Conventional Farming \\
\hline $\mathrm{pH}$ & 6.49 & 6.81 \\
Eh $(\mathrm{Mv})$ & 45.04 & 1.16 \\
OC(\%) & 2.80 & 1.66 \\
Total-N(\%) & 0.32 & 0.57 \\
C/N Ratio(\%) & 9.33 & 2.93 \\
Av-P(ppm) & 10.8 & 4.81 \\
Av-K(me/100g) & 2.89 & 1.61 \\
Base Saturation(\%) & 55.94 & 27.03 \\
CEC (me/100g) & 28.20 & 37.36 \\
Total Colony (Cfu/g) & 7.13 & 6.82
\end{tabular}

Note. Var- Variables; Eh- Redox Potential; OC-Organic Carbon; Av-P- Available P; Av-K- Available K; CECCation Exchange Capacity.

\subsection{Indicator Correlation}

A correlation test is performed to calculate correlation using diverse data while still demonstrating its correlation. This correlation analysis uses an equivalent of 5\% ( $\alpha$ 0.05). Chandel et al. (2018) stated that two indicators are correlated with the value of Pearson getting closer to 1 or $\mathrm{I}-1 \mathrm{I}$ and P-value of $<0.05$. Based on the correlation analysis (Table 3.) indicates that some indicators have a strong correlation, both positive and negative. The relationship between $\mathrm{pH}$ and $\mathrm{CEC}$ has a positive correlation $(\mathrm{R}=0.37)$ where the high $\mathrm{pH}$ value will increase also the value of the Ktyang, the land that has high CEC Al da Fe was joined by the Colloid, so it could be a pH buffer soil (Prabowo, 2019). $\mathrm{Ph}$ is positively correlated with $\mathrm{N}$ total $(\mathrm{r}=0.54)$. According to Afandi et al. (2015) the provision of organic fertilizer in the form of manure and residual straw can increase the $\mathrm{pH}$ of soil although still in the category of sour to neutral, increased soil $\mathrm{pH}$ caused by the process of decomposition and release of organic acids or mineralization of organic matter and able to increase $\mathrm{N}$ total in the soil.

Content of $\mathrm{pH}$ correlates negatively with C-organic, BS (Base Saturation), available K, Redox Potential, and C/N ratio $(\mathrm{r}=-0.58 ; \mathrm{r}=-0.49 ; \mathrm{r}=-0.56 ; \mathrm{r}=-0.82 ; \mathrm{r}=-0.42)$ This suggests that a high $\mathrm{pH}$ causes a reaction with $\mathrm{Ca}$ and $\mathrm{Mg}$ forming insoluble compounds in water and being unavailable to plants (Sudaryono, 2009), please note that the Ca and $\mathrm{Mg}$ that exist in the soil scream complex affects the $\mathrm{CEC}$ and base saturation. Table 3 indicates that $\mathrm{C}$-organic is positively correlated with BS (Base Saturation), redox and $\mathrm{C} / \mathrm{N}$ ratio $(\mathrm{r}=0.66 ; \mathrm{r}=0.78 ; \mathrm{r}=0.76)$ of research by Ispandi (2004) suggests that organic materials may affect the availability of bases cations such as $\mathrm{K}+, \mathrm{Ca} 2+, \mathrm{Na}+$, and $\mathrm{Mg} 2+$.

Table 4. Correlation analysis results

\begin{tabular}{|c|c|c|c|c|c|c|c|c|c|}
\hline$\overline{V a r^{a)}}$ & $p H$ & $A v-P$ & $O C$ & Total-N & $C E C$ & $B S$ & $A v-K$ & $T C P$ & $E h$ \\
\hline$\overline{A v-K}$ & $-0,20$ & & & & & & & & \\
\hline $\mathrm{OC}$ & $\underline{-0,58}$ & $0,56^{* *}$ & & & & & & & \\
\hline Total-N & $0,54 * *$ & $-0,58$ & & & & & & & \\
\hline CEC & $0,37^{*}$ & $-0,21$ & $-0,21$ & 0,32 & & & & & \\
\hline $\mathrm{BS}$ & $-0,49$ & 0,35 & $0,66^{* *}$ & $-\underline{0,48}$ & $-0,71$ & & & & \\
\hline$A v-K$ & $\underline{-0,56}$ & $-0,22$ & 0,25 & $-0,39$ & $-0,31$ & $0,39^{*}$ & & & \\
\hline TCP & $-0,19$ & 0,77 & 0,34 & $-0,30$ & $-0,29$ & 0,35 & $0,47 * *$ & & \\
\hline $\mathrm{Eh}$ & $\underline{-0,82}$ & 0,30 & $0,78 * *$ & $-0,52$ & $-0,20$ & $0,58 * *$ & $0,43 *$ & 0,28 & \\
\hline C/N Ratio & $\underline{-0,54}$ & $0,48^{* *}$ & $0,76^{* *}$ & $\underline{-0,91}$ & $-0,29$ & $0,52 * *$ & 0,29 & 0,31 & $0,60 * *$ \\
\hline
\end{tabular}

${ }^{a)}$ Var- Variables; Av-P - Available P; OC- Organic Carbon; CEC- Cation Exchange Capacity; BS- Base Saturation; Av-K- Available K; TCP- Total Colony Plate; Eh- Redox Potential

The asterisk means a positive correlation. The underlined values means a negative correlation.

**Significant correlation at a 0.05 level. 


\subsection{Soil Fertility Index}

Analysis of the soil fertility index by determining the Minimum Soil Fertility Indicator (MSFI). MSFI is a selected indicator (representative) and has an eigenvalue of $\geq 1$ or a minimum value of $60 \%$. To determine the MSFI and soil Fertility index was determined using the statistical analysis of PCA (Pearson Components Analysis) (Xie et al., 2015). The results of the PCA analysis shows 6 selected indicators have a high sensitivity level (representative) of 10 indicators to be the main component or MSFI to determine the value of soil fertility.

Table 4. PC1 representing 49.1\% data for soil fertility, selected C-organic, BS (Base Saturation), redox potential (Eh), and $\mathrm{C} / \mathrm{N}$ ratios have high weights and are positively correlated. On PC 2 representing 15\% data to determine soil fertility, the indicator chosen is $\mathrm{K}$ available, the indicator has a high weight because only one indicator selected is called Independent. PC 3 represents $11 \%$ data to determine soil fertility, selected CEC as an indicator, and has a high weight as well as an independent indicator. The six indicators selected as Minimum Soil Fertility Indicators (MSFI) include $\mathrm{C}$-organic, BS (base saturation), redox, $\mathrm{C} / \mathrm{N}$ ratio, $\mathrm{K}$ available, and $\mathrm{CEC}$ (cation exchange capacity) sorted from highest to lowest proportion values.

Table 5. Minimum soil fertility indicator analysis results

\begin{tabular}{llll}
\hline Eigenvalue & 4,9974 & 1,5021 & 1,0996 \\
Proportion & 0,5 & 0,15 & 0,11 \\
Cumulative & 0,5 & 0,65 & 0,76 \\
\hline Variable $^{a)}$ & $P C 1$ & $P C 2$ & $P C 3$ \\
\hline $\mathrm{pH}$ & $-0,349$ & $-0,146$ & $-0,294$ \\
$\mathrm{Av}-\mathrm{P}$ & 0,215 & $-0,583$ & $-0,254$ \\
$\mathrm{OC}$ & $* \mathbf{0 , 3 7 9}$ & $-0,245$ & 0,112 \\
Total-N & $-0,359$ & 0,119 & $-0,098$ \\
$\mathrm{CEC}$ & $-0,234$ & $-0,227$ & $* \mathbf{0 , 6 8 5}$ \\
$\mathrm{BS}$ & $* \mathbf{0 , 3 5 3}$ & 0,083 & $-0,408$ \\
Av-K & 0,239 & $* \mathbf{0 , 5 8 8}$ & 0,195 \\
TCP & 0,211 & 0,332 & $-0,16$ \\
Eh & $* \mathbf{0 , 3 6 8}$ & 0,001 & 0,339 \\
C/N Ratio & $* \mathbf{0 , 3 7 8}$ & $-0,223$ & 0,109
\end{tabular}

${ }^{a)}$ Av-P- Available P; OC- Organic Carbon; CEC- Cation Exchange Capacity; BS- Base Saturation; Av-KAvailable K; TCP- Total Colony Plate; Eh- Redox Potential.

The asterisk means minimum soil fertility indicator.

The results (table 5.) obtain a weighted index or a result Wi divided by the analysis of the proportion analysis that appears in the main component by scoring. The assessment result of issuing an analysis on a lot of points then added and modified according to (Gerwin et al., 2018).

Table 6. calculation of Minimum Soil Fertility Indicator

\begin{tabular}{llll}
\hline MSFI $^{*}$ & Proportion & Cumulative & Weight Index* \\
\hline Organic Carbon & 0,50 & 0,76 & 0,16 \\
C/N Ratio & 0,50 & 0,76 & 0,16 \\
Base Saturation & 0,50 & 0,76 & 0,16 \\
Eh & 0,50 & 0,76 & 0,16 \\
Available K & 0,15 & 0,76 & 0,20 \\
CEC & 0,11 & 0,76 & 0,14
\end{tabular}

*Weight index was obtained from the proportion divided by cumulative; MSFI- Minimum Soil Fertility Indicator; Eh- Redox Potential; CEC- Cation Exchange Capacity

The soil fertility scoring is based on the Indonesian Agency for Agricultural Research and Development (2005) and Wander (2002) can be seen (Table 6.). The results showed from the calculation of the soil fertility index were 
then classified according to (Bagherzadeh et al., 2018) that the soil fertility class is divided into very low, low, medium, high, and very high. After the indicators were selected as MSFI was consequently given a score based on the arcades from the Soil Research Institue (2009), earlier the next scoring has conducted the assessment of the Soil Fertility Index (SFI). The soil fertility index class is divided into very low, low, medium, high, and very high (Bagherzadeh et al., 2018) receptive to the value of the fertility index of the soil in the 0-1 (Mukashema, 2007).

Table 7. Scoring of Minimum Soil Fertility Indicators

\begin{tabular}{llllllllllll}
\hline & \multicolumn{10}{c}{ Scoring } \\
\cline { 3 - 11 } No & MSFI & 1 & 2 & 3 & 4 & 5 & 6 & 7 & 8 & 9 & 10 \\
\hline 1 & Organic Carbon & 3 & 3 & 3 & 3 & 3 & 3 & 3 & 3 & 3 & 3 \\
2 & C/N Ratio & 1 & 1 & 2 & 2 & 2 & 2 & 2 & 2 & 2 & 2 \\
3 & Base Saturation & 2 & 2 & 3 & 3 & 3 & 3 & 3 & 3 & 3 & 3 \\
4 & Redox Potential & 3 & 3 & 3 & 3 & 3 & 3 & 3 & 3 & 3 & 3 \\
5 & Available K & 4 & 4 & 4 & 4 & 4 & 4 & 4 & 4 & 4 & 4 \\
6 & CEC & 2 & 2 & 2 & 2 & 2 & 2 & 2 & 2 & 2 & 2
\end{tabular}

*Sample 1-2 are conventional paddy fields; 3-10 are organic paddy fields

According to the classification of Baghserzadeh et al. (2018) Organic rice fields have an average value of soil fertility index 0.96 (very high) while in conventional rice fields have an average value of the fertility index of soil 0.85 (high). The difference in the management system of paddy fields makes the difference in the index value in both, organic rice fields are given input of organic material in the form of manure and residual straw, while conventional rice fields and urea. According to Van Luween et al. (2015) the differences in land management, as well as given inputs, will make a difference in soil properties, one of which is a biological activity that affects the availability of nutrients, nutrients, or soil physical properties.

Table 8. Soil Fertility Index on Paddy Field with several systems

\begin{tabular}{llll}
\hline No & Paddy Field Sites & Soil Fertility Index & Soil Fertility Classified \\
\hline 1 & Organic & 0.96 & Very High \\
2 & Conventional & 0.85 & High
\end{tabular}

Organic farming is regarded as a farming system where soil fertility is regarded as the basis of production and therefore can optimize the quality of all the factors involved, especially the soil quality. Following the statement of Mustikaningrum (2018), the high content of organic matter in the soil will enhance the chemical, physical and biological properties of the soil and, in consequence, the quality of soil will also increase.

\section{Conclusions}

The value of soil fertility in rice soil in the village of Pereng managed by organically has better soil fertility compared to conventional management with the value of fertility index of land respectively 0.96 and 0.85 . Soil fertility is determined using MSFI (Minimum Soil Fertility Index) from various indicators of soil fertility. The principal component analysis (PC in this study has represented $75 \%$ of the total data. This study relates to the sustainability of nature that can be utilized continuously.

\section{Acknowledgments}

This study was supported by the Ministry of Research, Technology, and Higher Education, Republic of Indonesia, and the University of Sebelas Maret.

\section{References}

Adepetu, J. A., Nabhan, H., \& Osinubi, A. (2000). Simple soil, water \& plant testing techniques for soil resource management. FAO Proceedings of a Training Course, p. 166. Retrieved from https://www.researchgate.net/profile/Anoop_Srivastava7/post/How_to_predict_soil_attributes_of_highly_st eep_hilly_slopes_not_accessible_for_sampling/attachment/59d6447̄79197b807799fbc8/AS\%3 A 44890459 3448960\%401484038603062/download/misc28.pdf

Afandi Nur Fahriansyah, Siswanto Bambang, \& Nuraini Yulia. (2015). The effect of giving various types of organic materials on the properties of soil chemistry in the growth and production of sweet potato crops in Entisol Ngrangkah Pawon, Kediri. Journal of Land and Land Resources, 2(2), 237-244. Retrieved from 
https://jtsl.ub.ac.id/index.php/jtsl/oai

Andrews, S. S., Karlen, D. L., \& Cambardella, C. A. (2004). The soil management assessment framework: A quantitative soil quality evaluation method. Soil Science Society of America Journal, 68(6), 1945-1962. https://doi.org/10.2136/sssaj2004.1945

Bagherzadeh, A., Gholizadeh, A., \& Keshavarzi, A. (2018). Assessment of soil fertility index for potato production using integrated Fuzzy and AHP approaches Northeast of Iran. Eurasian Journal of Soil Science, 7(3), 203-212. https://doi.org/10.18393/ejss.399775

Chandel, S., Hadda, M. S., \& Mahal, A. K. (2018). Soil quality assessment through minimum data set under different land uses of submontane Punjab, Communications in Soil Science and Plant Analysis. Taylor \& Francis, 49(6), 658-674. https://doi.org/10.1080/00103624.2018.1425424

Chen S., Lin B., Li Yanqiang, \& Zhou Sining. (2020). Spatial and temporal changes of soil property and soil fertility evaluation in a large grain-production area of subtropical plain, China. Geoderma, 357, 113937. https://doi.org/10.1016/j.geoderma.2019.113937

Fageria, N. K., dos Santos, A. B., \& Cobucci T. (2011). Zinc nutrition of lowland rice. Communications in Soil Science and Plant Analysis, 42, 1719-1727. https://doi.org/10.1080/00103624.2011.584591

Feng, W., Plante, A. F., \& Six, J. (2013). Improving estimates of maximal organic carbon stabilization by fine soil particles. Biogeochemistry, 112, 81-93. https://doi.org/10.1007/s10533-011-9679-7

Gerwin, W., Repmann Frank, Galatsidas, S., \& V. Desponia. (2018). Assessment and qualification of marginal lands for biomass production in Europe Using Soil Quality Indicators. SOIL, 4, 267-290. https://doi.org/10.5194/soil-4-267-2018

Gupta, R. K., Singh, A., Singh, Y., Thind, H. S., Singh, B., \& Singh, V. (2019). Rice straw biochar improves soil fertility, growth \& yield of rice-wheat system on sandy loam soil. Experimental Agriculture, Cambridge, 1-14. https://doi.org/10.1017/S0014479719000218

Indonesian Agency for Agricultural Research and Development, Ministry of Agriculture. (2009). The Physical Properties of the Soil and Its Method of Analysis (in Indonesian), Department of Agriculture, Bogor.

Indonesian Soil Research Institute. (2005). Analysis of Soil Chemistry, Plant, Water and Fertilizer (in Indonesian), Department of Agriculture, Bogor.

Ispandi, A., \& A. Munip. (2004). Effectiveness of NPK fertilizer and frequency of fertilizer in improving nutrient absorption and peanut production in Alfisol dry land. Thing, 151-161. Malang. Retrieved from https://i-lib.ugm.ac.id/jurnal/detail.php?dataId=5661

Ju, C., \& Dan Zhang, J. (2014). Effect of water stress on photosystem in photochemistry and its thermostability in wheat plants. Journal of Experimental Botany, 50, 1196-1206. https://doi.org/10.1093/jxb/50.336.1199

Khadka, D., Lamichane, S., Shrestha, S. R., \& Pant, B. B. (2017). Evaluation of Soil Fertility Status of Regional Agricultural Research Station, Tarahara, Sunsari, Nepal. Eurasian Journal of Soil Science, 6(4), 295. https://doi.org/10.18393/ejss.303512

Khaki, D. B., Honoarjoo, N., Davatgar, N., Jalalian, A., \& Golsefidi T. H. (2017). Assessment of Two Soil Fertility Indexes to Evaluate Paddy Fields for Rice Cultivation. Journal Sustainability, (9), 1299. https://doi.org/10.3390/su9081299

Kiboi, M. N., Ngetich, K. F., Fliessbach, A., Muriuki, A., \& Mugendi, D. N. (2019). Soil fertility inputs and tillage influence on maize crop performance and soil water content in the Central Highlands of Kenya. Agricultural Water Management, 217, 316-331. https://doi.org/10.1016/j.agwat.2019.03.014

Lantoi, R. R., Darman, S., \& Patadungan, Y. S. (2016). Assessment of wetland rice soil quality at several locations in Palu Valley using a lowery scoring method (in Indonesian). Agroland Journal, 23(3), 243-250.

Liu, Z. G. (1985). Chemistry of Variable Charge Soils. Science Press. Beijing.

Martinez-Salgado, M. M., Gutierrez-Romero, V., Jannsens, M., \& Ortega-Blu, R. (2010). Biological soil quality indicators: a review. Current Research, Technology and Education Topics in Applied Microbiology and Microbial Biotechnology, 319-328. Retrieved from https://www.researchgate.net/publication/285738755

McBratney, A., Field, D. J., \& Koch, A. (2014). The dimensions of soil security. Geoderma, 213, 203-213. https://doi.org/10.1016/j.geoderma.2013.08.013 
Mueller, L., Sheudshen, A. K., \& Eulenstein, F. (2016). Novel Methods for Monitoring and Managing Land and Water Resources in Siberia. Spring Water. https://doi.org/10.1007/978-3-319-24409-9

Mukashema, A. (2007). Mapping and Modelling Landscape-based Soil Fertility Change in Relation to Human Induction. Ph.D. Dissertation. International Institute for Geo-Information Science and Earth Observation Enschede, The Netherlands. $\quad$ Retrieved from https://webapps.itc.utwente.nl/librarywww/papers_2007/msc/nrm/mukashema.pdf

Mustikaningrum, I. A., Supriyadi, Herawati, A., Purwanto, P., \& Sumani, S. (2018). Soil quality assessment in organic and non-organic paddy fields in Susukan, Indonesia. Bulgarian Journal of Agricultural Science, 24(5), 777-784. https://doi.org/10.17951/pjss.2018.51.2.173

Nemecek Thomas, Dubois David, E. H. Oliver, \& Gailard Gerard. (2011). Life cycle assessment of Swiss farming systems: I. Integrated and organic farming. Agricultural Systems, 104, 217-232. https://doi.org/10.1016/j.agsy.2010.10.002

Noviyanto, A., Purwanto, Minardi, S., \& Supriyadi. (2017). The assessment of soil quality of various age of land reclamation after coal mining: a chronosequence study. Journal of Degraded and Mining Lands Management, 5, 1009-1018. https://doi.org/10.15243/jdmlm.2017.051.1009

Oechaiyaphum, Kaewjai, Ullah, H., Shrestha, R. P., \& Datta, A. (2020). Impact of long-term agricultural management practices on soil organic carbon and soil fertility of paddy fields in Northeastern Thailand. Geoderma Regional, e00307. https://doi.org/10.1016/j.geodrs.2020.e00307

Plant, R. E. (2001). Site-specific management: the application of information technology to crop production. Computers and Electronics in Agriculture, 30, 9-29. https://doi.org/10.1016/S0168-1699(00)00152-6

Prabowo, N. A., \& Sudarsono. (2019). Analysis of fertility distribution land of paddy field (a case study of the agricultural area of Semarang city). Journal of Scientific Cendikia.

Purwanto, E. (2008). Study of Media Planting and Concentricities Compassion to the growth of fence range cuttings (Jatropha Curcas I). Agronomic study Program. Sebelas Maret University. https://core.ac.uk/reader/12349250

Recena Ramiro, Fernandez-Cabanas, M. V., \& Delgado Antonio. (2019). Soil fertility assessment by Vis-NIR spectroscopy: predicting soil functional rather than availability indices. Geoderma, 337, 368-374. https://doi.org/10.1016/j.geoderma.2018.09.049

Reeuwijk, L. P. V. (2002). Procedures for soil analysis 6th edition. International Soil Reference and Information Centre.

Sari, M. N., Sudarsono, \& Darmawan. (2017). Effect of organic matter on phosphate availability in soils rich of al and fe. Buletin Tanah dan Lahan, 1(1), 65-71. https://doi.org/10.1590/1413-70542016404023016

Sudaryono. (2009). The level of fertility of the Ultisol land on the Sangatta Kaltim coal mining land. Journal of Environmental Engineering, 10(3), 337-346. https://doi.org/10.29122/jtl.v10i3.1480

Supriyadi, Dewi, S. W., Nugrahani, D., R. A. Adila, Haryuni, \& Sumani. (2020). The Assessment of Soil Quality Index for Paddy Fields with Indicator Biology in Jatipurno Districts, Wonogiri. Modern Applied Science, 14(1). https://doi.org/10.5539/mas.v14n1p20

Supriyadi, Purwanto, \& Visnu. (2015). To Study the Effect Of Soil Macrofauna On Soil Quality In Keduang Sub Watershed Based Agroforestry System, Karanganyar. International Journal of Agriculture, Forestry and Plantation, 1, 78-84. Retrieved from https://ijafp.com/wp-content/uploads/2015/10/AG-58.pdf

Supriyadi, Purwanto, Sarijan, A., Mekiuw, Y., Ustiatik, R., \& Prahesti, R. R. (2017). The Assessment of Soil Quality at Paddy Fields in Merauke, Indonesia. Bulg. J Agricultural Science, 23(3), 443-448. Retrieved from

https://www.researchgate.net/publication/318225326_The_assessment_of_soil_quality_at_paddy_fields_in _Merauke_Indonesia

Supriyadi, Rachmawati Septiana, Herawati, A., \& Purwanto. (2018). Soil Quality Assessment of The Rainfed Lowland Rice Field Under Organic and Conventional Farming Systems in Kaliwungu. Polish Journal of Soil Science, 51(2), 173-183. https://doi.org/10.17951/pjss.2018.51.2.173

The Central Statistic Agency (BPS) of Karanganyar Regency. (2018). Mojogedang Sub-district in numbers. Central Statistical Agency of Karanganyar Regency. Retrieved from https://karanganyarkab.bps.go.id/ 
The Central Statistic Agency (BPS) of Karanganyar Regency. (2019). Karanganyar in Numbers. Karanganyar: Bappeda of Karanganyar Regency and the Central Statistics Agency of Karanganyar Regency. Retrieved from https://karanganyarkab.bps.go.id/

Van Leeuwen, J. P., Lehtinen, T., Lair, G. J., Bloem, J., Hemerik, L., Ragnarsdóttir, K. V., Gisladottir, G., Newton, J. S. \& de Ruiter, P. C. (2015). An ecosystem approach to assess soil quality in organically and conventionally managed farms in Iceland and Austria. SOIL, 1(1), 83-101. https://doi.org/10.5194/soil-1-83-2015

Wahyuni, S., Rianto, S., Muanisah, U., \& Setyanto, P. (2016). Utilization of organic fertilizer to increase bacterial population and production of rice crops Gogorancah. Proceeding Biology Education Conference: Biology, Science, Environmental \& Learning, 13(1), 752-756. Retrieved from https://jurnal.uns.ac.id/prosbi/article/view/5902

Wander, M. M., Gerald, L. W., Nissen, T. M., Bollero, G. A., Andrews, S. S., \& Deborah, A. C. (2002). Soil quality: Science and process. Agronomy Journal, 94, 23-32. https://doi.org/10.2134/agronj2002.0023

Xie, L. W., Zhong, J., Chen, F. F., Cao, F. X., Li, J. J. \& Wu, L. C. (2015). Evaluation of soil fertility in the succession of karst rocky desertification using principal component analysis. Solid Earth, 6(2), 515-524. https://doi.org/10.5194/se-6-515-2015

Yi, Z., Jinchao, F., Dayuan, X., Weiguo, S., \& Axmacher, J. C. (2012). A Comparison of terrestrial arthropod sampling methods. Journal of Resources and Ecology, 3, 174-182. https://doi.org/10.5814/j.issn.1674-764x.2012.02.010

\section{Copyrights}

Copyright for this article is retained by the author(s), with first publication rights granted to the journal.

This is an open-access article distributed under the terms and conditions of the Creative Commons Attribution license (http://creativecommons.org/licenses/by/4.0/). 